\title{
PROPERTY, CREDIT, AND REGULATION MEET INFORMATION TECHNOLOGY: CLEARANCE AND SETTLEMENT IN THE SECURITIES MARKETS
}

\author{
Charles W. Mooney, Jr.*
}

\section{INTRODUCTION}

The structure and operation of today's financial markets largely reflect relatively recent advances in electronic information technology and its applications. The ability of market participants to communicate and store vast amounts of information at very high speeds has irreversibly transformed the landscape of these markets. The age of the global, twenty-four-hour-day market is at hand. ${ }^{1}$ Significantly, these developments seem to be unending; change continues at an accelerating pace. This article reflects on the implications of these developments for those who deal with commercial law, in particular the laws relating to the transfer and pledge of investment securities within the structure of modern securities markets. ${ }^{2}$

The principal goal of this article is to identify and illuminate the attributes of electronic information technology applications in the context of commercial law. By explicitly drawing attention to the relevant attributes of technology, this taxonomy may assist those who are called upon to create (legislatively, judicially, and administratively), administer, and interpret commercial law.

Consideration of securities market clearing and settlement provides a particularly useful and timely context within which to examine technology and commercial law. Clearance and settlement comprise the process whereby securities market participants consummate their agreements to buy and sell securities (trades). The buyer pays the seller, and the seller "delivers" (transfers a property interest in) the securities. The securities markets are highly automated, relying heavily on information technology, and systems for

\section{Copyright $\odot 1992$ by Law and Contemporary Problems}

* Professor of Law, University of Pennsylvania Law School.

I wish to thank Professor Lynn M. LoPucki of the University of Wisconsin Law School for his comments on an earlier draft of this article and for many valuable discussions before and during its preparation.

1. See, for example, Office of Technology Assessment ("OTA"), Trading Around the Clock: Global Securities Markets and Information Technology (Govt Printing Office, 1990) (background paper, OTA-BP-CIT-66).

2. By "commercial law" I mean laws relating to the contract and property rights aspects of securities transactions as contrasted with laws and administrative regulations dealing with the regulation and supervision of securities markets and financial institutions that participate in those markets. As will be shown, however, both regimes must be considered together. 
clearing and settlement are now being examined closely with a view toward continuing reforms. ${ }^{3}$ In addition, the principal commercial law dealing with securities transfer, article 8 of the Uniform Commercial Code ("UCC"), ${ }^{4}$ is now being revised. A committee of the American Bar Association's Section of Business Law has issued a preliminary report that calls for revision of article $8,{ }^{5}$ and the drafting committee of the National Conference of Commissioners on Uniform State Laws is now at work. ${ }^{6}$ Finally, in 1990 Congress enacted legislation that gives the Securities and Exchange Commission the power to issue preemptive federal regulations dealing with the transfer and pledge of securities. ${ }^{7}$

In addition to its taxonomic agenda, this article illustrates the challenges that confront legal "scientists," legal "engineers," and legal "technicians" operating within the penumbra of electronic information technology. These challenges bear much in common with the obstacles confronting anyone working on any law reform project or social problem. Nonetheless, the taxonomy of the attributes of electronic information technology applications reveals some special, even unique, considerations for the legal specialists.

3. See Report: Clearance and Settlement Systems in the World's Securities Markets (Group of Thirty, 1989) (making nine proposals for reforming the world's securities markets) ("G-30 Report"). The Group of Thirty is a "private sector group concerned with the working of the International Financial System." Id at i. See also Improving International Settlement (Federation Internationale Des Bourses de Valeurs, 1989) (report concerning clearance and settlement in the world's securities markets); Study of International Clearing and Settlement (Office of Technology Assessment, 1989) (same); Report of the Technical Committee of IOSCO on Clearing and Settlement (International Organization of Securities Commissions, 1990) (same).

4. The American Law Institute, Uniform Commercial Code: 1990 Official Text With Comments art 8 (Investment Securities) (West, 12th ed 1990) ("UCC').

5. See American Bar Association, Section of Business Law, Interim Report of the Advisory Committee on Settlement of Market Transactions (Exposure Draft, Feb 15, 1991) ("ABA Interim Report"). For other recent critiques of article $\mathbf{8}$, see Charles W. Mooney, Jr., Beyond Negotiability: A New Model for Transfer and Pledge of Interests in Securities Controlled by Intermediaries, 12 Cardozo L Rev 305 (1990); Jeanne L. Schroeder \& David Gray Carlson, Security Interests Under Article 8 of the Uniform Commercial Code, 12 Cardozo L Rev 557 (1990).

6. A draft revision of article 8, dated May 1, 1992 ("1992 Draft Article 8") received its "first reading" in August 1992, at the Annual Meeting of the National Conference of Commissioners on Uniform State Laws. It is likely that the revision will be promulgated officially in 1993.

7. Market Reform Act of 1990, Pub L No 101-432 (1990), amending $\$ 17 A(a)(2)$ of the Securities Exchange Act of 1934, 15 USC \& 78q-1. On March 14, 1986, the Department of Treasury proposed new federal regulations governing the transfer and pledge of U.S. treasury securities, called the Treasury/Reserve Automated Debt Entry System (“TRADES"). 51 Fed Reg 8846 (1986), to be codified at 31 CFR pt 357. A substantially revised version of proposed TRADES regulations was published on November 28, 1986. 51 Fed Reg 43027 (1986), to be codified at 31 CFR pt 357. Another substantially revised version was proposed recently. 57 Fed Reg 12244 (1992), to be codified at 31 CFR pt 357 (proposed April 9, 1992), amended by 57 Fed Reg 20572 (1992). Final regulations have not been issued. 
Attributes of Electronic Information Communication and STORAGE TECHNOLOGY

How does electronic information technology differ from traditional media? Professor Katsh has noted four basic, if very general, differences: ${ }^{8}$

(1) Amount of information that can be stored ("Storage Capacity"). There are virtually no limits to the amount of information that can be stored on computers. The seemingly constant development of more advanced computer chips continues to make it possible to store more information in less space.

(2) Speed of transmission of information ("Transmission Speed"). Electronic communications are virtually instantaneous. Enhancements in media, such as optic fiber cables, allow an increasing volume of information to be transmitted simultaneously.

(3) Ease of accurate reproduction of, modification of, and access to information ("Ease of Access"). Computer technology also makes it possible to reproduce, modify, search for, and discover information with great ease and accuracy.

(4) Speed of revision, modification, and discovery of information ("Speed of Access"). Similarly, computer technology allows very rapid reproduction, modification, and discovery of information.

There are other characteristics of electronic information communication and storage, some of which derive from the four just mentioned, that are particularly significant in the context of creating, administering, and interpreting law. ${ }^{9}$ For example:

(5) Reduced costs of communication ("Reduced Cost"). Advances in the application of electronic communication have drastically reduced the costs of information communication and storage. One expert has estimated that these costs have been reduced by ninety-five percent during the last twenty-five years. ${ }^{10}$

(6) Complexity of operational systems and relationships ("System Complexity"). The operational systems that apply electronic information communication and storage technology and the resulting relationships are enormously complex. Thus, these systems are often opaque, or even invisible, to the uninitiated. Many of the lawyers and judges that interact with these systems probably remain (more or less) uninitiated. The discussion below of securities market clearing and settlement will further illuminate the

8. M. Ethan Katsh, The Electronic Media and the Transformation of Law 21 (Oxford U Press, 1989).

9. I make no claim that the taxonomy proposed here is exhaustive.

10. Paul F. Glaser, The Intersection of Technology and Financial Services, in Daniel R. Siegel, ed, Innovation and Technology in the Markets 13, 16 (Probus, 1990). Presumably that estimate refers to a perunit cost. Because more information is being communicated and stored today, it is possible that the aggregate expenditures for communication have increased. 
characteristic complexity of these systems and the relationships that they create.

(7) Complexity of the electronic technology that supports the complex operational systems ("Technology Complexity"). Just as the operational systems are complex, so are the sophisticated computer hardware and software that drive these systems.

(8) Facilitation of both centralized and decentralized systems ("Centralization/Decentralization"). The Storage Capacity, Transmission Capacity, Ease of Access, and Revision Speed characteristics allow systems to decentralize by making remote access feasible. On the other hand, the volume of information and number of participants involved in a system do not prevent complete or partial centralization of that system.

(9) The creation and packaging of new kinds of property, products, and relationships ("New Property"). Electronic information communications and storage have made possible the creation of new kinds of property, products, and relationships. Examples are innovations in securities market trading ${ }^{11}$ and the products that are traded and used. ${ }^{12}$

(10) Frequency of advances/changes in technology and in the operational systems through which technology is applied ("Frequent Change"). Advances and changes in available technology and in the systems that actually employ it continue to occur at a seemingly exponential pace. Much of what is here today will almost certainly not be around tomorrow. And the specifics of what is likely to be around tomorrow are increasingly hard to predict.

(11) Difficulty of predicting the timing and nature of advances/changes in technology and its operational systems ("Unpredictability"). The New Property and the Frequent Change characteristics result in another attribute-unpredictability. Although the first ten attributes of information technology seemingly point to the directions in which this technology will continue to proceed, predicting the details of future developments is like shooting at a fast-moving, often invisible target.

The value of identifying these attributes of electronic communications technology is best illustrated by examining these attributes in the context of a particular legal regime. Before doing so in Part III, Part II provides necessary background with a brief description of the process of clearance and settlement in the U.S. securities markets.

11. See, for example, Sanford Grossman, Trading Technology and Financial Market Stability, in Daniel R. Siegel, ed, Innovation and Technology in the Markets 47-57 (Probus, 1990); Richard O. Scribner, The Technological Revolution in Securities Trading: Can Regulation Keep Up?, in Anthony Saunders \& Lawrence J. White, eds, Technology and the Regulation of Financial Markets 19-29 (D.C. Heath, 1986).

12. See, for example, Glaser, The Intersection of Technology and Financial Services at 17-18 (cited in note 10 ). 
II

\section{Securities Market Clearance and Settlement:} An Overview of the Process and Participants

Securities market operations applicable to the process of trading as well as the processes that occur after trades are made (clearance and settlement) have been radically transformed during the last quarter century or so. Many of the most significant characteristics of modern securities markets result directly from the application of advanced electronic information communication and storage technology. In particular, these advances now permit a speed and volume of market transactions that could not have been imagined during the 1960s. The following passage is illustrative:

Technological and institutional innovations have radically transformed financial markets in the U.S. and around the world, permitting and encouraging spectacular increases in the volume of securities trading of all kinds. In 1960, 766 million shares were traded on the NYSE, while in 1987 more than 900 million shares changed hands in an average week. More shares were traded on the lowest volume day in 1987 than in any month in 1960. And more shares changed hands in the first 15 minutes of trading on October 19 and 20, 1987 than in any week in 1960.

Increases in trading have been even more spectacular in other markets. In 1960 or 1970 , there were no organized markets in derivative securities. Today, the dollar value of contracts traded on the stock market futures market alone significantly exceeds the volume of trade on the stock market itself-and the volume of trade in stock market futures is nearly equalled by trade in index options. . . . Today, there is every reason to expect trading volumes to continue increasing. Already, the NYSE is preparing itself for a one-billion-share day. And with increasing international linkages among markets, an inexhaustible variety of securities are tradable 24 hours a day.

In the narrow sense of permitting trade to take place between consenting adults, these statistics make it obvious that our financial markets have become much more efficient over time. Unloading a one-million-dollar portfolio of stock easily might have cost $\$ 10,000$ or more in 1960 ; but today a functionally-equivalent transaction can be carried out in the futures market for a couple of hundred dollars or less. To a great extent, it is reductions in trading costs that have allowed volume to skyrocket so dramatically. ${ }^{13}$

These dramatic developments in the nature and volume of securities market trading by market professionals-the so-called "front office" -could not have taken place in the absence of equally profound developments in the process of clearance and settlement-the so-called "back office." However securities are traded (such as on organized exchanges or in an over-thecounter market), buyers must arrange to pay for securities bought and sellers must arrange to transfer ownership of the securities sold. The arrangements might call for each trader to meet face-to-face with each trading partner so that the securities involved in each trade can be physically delivered to the buyer against simultaneous payment to the seller in currency or check. But, for active securities market participants who make many trades every business day, that settlement structure would not work. The systems for clearing

13. Lawrence H. Summers \& Victoria P. Summers, When Financial Markets Work Too Well: A Case for a Securities Transaction Tax, in Daniel R. Siegel, ed, Innovation and Technology in the Markets $151-52$ (Probus, 1990). The impact of technology on the creation of new products was mentioned above. See text at note 12. 
(comparing, matching, and confirming trades so that each party is assured that the trades have been made according to the mutually agreed upon terms) and settling (transferring interests in and paying for) securities trades reflect attempts to replicate, in some fashion, the certainty and safety of the simple face-to-face paradigm while avoiding its inefficiency and impracticability.

By the late 1960s, the back offices of the securities industry had fallen hopelessly behind the front offices, thereby giving rise to what is now known as the "paperwork crunch." 14 The industry responded by creating a system employing a securities depository to hold physical possession of securities, thereby allowing its participants to transfer securities among themselves by means of book entries made by the depository. ${ }^{15}$

The system that currently handles clearance and settlement for the New York Stock Exchange ("NYSE"), the American Stock Exchange ("AMEX"), and the National Association of Securities Dealers ("NASD") over-thecounter market involves both the Depository Trust Company ("DTC") 16 and the National Securities Clearing Corporation ("NSCC"). ${ }^{17}$ Settlement in these markets occurs on the fifth business day following the date of a trade $(T+5)$. Almost every aspect of the system is highly automated, including direct computer linkages between the trading systems and the clearance and settlement system. ${ }^{18}$ Not only does electronic communication reduce the movements of certificated securities among system participants, but it reduces the movement of paper communications as well.

The principal system operated by NSCC is called the "continuous net settlement" ("CNS") system. Following is a general description of how the system works:

Only trades in securities eligible for deposit with DTC can be cleared and settled in the CNS system, and on the settlement date [the fifth business day following the trade date] all of the securities to be delivered must be on deposit with DTC. Prior to the settlement date the trades among all of the participants are compared (matched) and netted with respect to each securities issue, with each participant ultimately becoming obligated to transfer or entitled to receive only a net quantity of securities that takes into account all of that participant's trades in that security issue. Also prior to the settlement date, NSCC becomes obligated to transfer and entitled to receive these netted amounts to or from each participant. On the payments side, all amounts to be paid and received by each broker-dealer participant also are netted, and NSCC

14. See American Bar Association, Section of Corporation, Banking and Business Law, Report of the Committee on Stock Certificates 37-43 (Am Bar Assn, 1975). Some securities firms even failed because of serious delays in payments for and deliveries of securities. SIPC and Customer Protection 1 (Securities Investor Protection Corporation, 1986).

15. The Depository Trust Co., Annual Report 1991 at 4 (1992) (“DTC 1991 Annual Report").

16. The Depository Trust Company, a New York limited purpose trust company, is the world's largest securities depository. Id at 33. It was formed in 1973 as a successor to the business of the New York Stock Exchange's Central Certificate Service, which was created to respond to the paperwork crunch of the late 1960s. The Depository Trust Co., Annual Report 1989 at 6 (1990).

17. NSCC was formed in 1977 to provide post-trade clearance and settlement services for trades on the NYSE, the AMEX, and the NASD over-the-counter trades; NSCC is owned jointly by the NYSE, AMEX, and NASD. Robert J. Woldow, An Overview of the Role of the National Securities Clearing Corporation in Equities Trading 1-2, 8 (unpublished manuscript, 1990). About $95 \%$ of all equities trades in the NYSE, AMEX, and NASD markets are cleared and settled through NSCC. Id at 7.

18. Id at 2-3. 
becomes obligated to pay and entitled to receive payment to or from each participant. Each participant becomes obligated to pay to or entitled to receive from NSCC only a single sum on account of all of its trades for all issues to be settled on that date. In sum, on each settlement date, each NSCC participant pays to or receives one sum of money from NSCC and each NSCC participant transfers to or receives from NSCC, by book entry on the books of DTC, a single quantity of each security issue involved.

Most large institutional investors employ a DTC participant custodian bank. Most of these investors allow their custodian banks to leave their securities in the custodian banks' accounts with DTC, registered in the name of DTC's nominee, although in theory the investors could request their DTC member-intermediary to withdraw and hold them or request that certificates be issued in the investors' own names. Thus, these market participants normally have no direct relationship with the issuers of securities of which they claim beneficial ownership. DTC participants expect DTC's nominee to become the registered owner of securities, and non-participant investors, in turn, look to the DTC members or other intermediaries. ${ }^{19}$

The netting of transfer and payment obligations in the CNS system reduces the aggregate amount of obligations that are outstanding and unperformed at any particular time. ${ }^{20}$ Because there is always a risk that a participant will not pay or transfer securities on the settlement date (settlement risk), ${ }^{21}$ the netting-induced reduction in unperformed obligations reduces the aggregate risk in the system. The aggregate risk also could be reduced by shortening the time between the trade date and the settlement date. ${ }^{22}$ The Group of Thirty ("G-30") Report recommends that settlement occur not later than $\mathrm{T}+3 .{ }^{23}$

Settlement in the CNS system exemplifies "street-side" settlementsettlement among the financial intermediaries acting for their disclosed or (usually) undisclosed customers. "Customer-side" settlement refers to (1) the payment to financial intermediaries by buying customers, (2) the transfer (by physical delivery or otherwise) of securities to buying customers, (3) the payment by financial intermediaries to selling customers, and (4) if the securities are not already controlled by the financial intermediary, the delivery of securities to financial intermediaries by selling customers. When the financial intermediary for a selling customer already controls the securities (such as in the financial intermediary's account with DTC), it is unnecessary for the customer to deliver to the financial intermediary the physical securities certificates to be sold. Similarly, when a buying customer allows its financial

19. Mooney, 12 Cardozo L Rev at $318-20$ (cited in note 5) (footnotes omitted). Funds and securities settlements in the CNS system are substantially (although not strictly) simultaneous (called "delivery versus payment" or "DVP" on the street), thereby reducing, but not wholly eliminating, the risk that a participant could receive securities in its DTC account and subsequently fail to make a net funds payment due NSCC. Note also that the system might be structured so that parties could negotiate and reach agreement as to the settlement date for a trade (that is the procedure in the government securities over-the-counter market), such as $T+1, T+5$, or $T+10$. However, there seems to be a general consensus that the benefits of standardized settlement dates in a netting system such as the CNS outweigh any perceived benefits of flexibility.

20. G-30 Report at 9, 36-43 (cited in note 3); see also Report on Netting Schemes 6 (Bank for International Settlements, 1989) (making the same point concerning netting in the payments system).

21. The default could arise out of insolvency or illiquidity of a system participant.

22. See Ananth Madhavan, Morris Mendelson \& Junius W. Peake, Risky Business: The Clearance and Settlement of Financial Transactions, $3 \mathrm{~J}$ Intl Sec Mkts 7 (1989).

23. G-30 Report at 14-15 (cited in note 3). 
intermediary to continue to control the securities, it eliminates the need for a subsequent physical delivery of securities certificates to the customer and another subsequent redelivery to an intermediary when the customer is ready to sell.

In part because the securities must be "in the system" (that is, on deposit with DTC) for settlement to occur in the CNS system, active market participants typically allow a financial intermediary to retain control of their securities at all times. ${ }^{24}$ Many individual "retail" customers also prefer the convenience of allowing their securities firm intermediaries to control securities for their account. Similarly, because not all banks and securities firms who control securities for their customers are direct DTC participants, some of them allow other ("upper-tier") financial intermediaries to control securities for them. ${ }^{25}$

This phenomenon of financial intermediary control necessarily involves risks. Securities firms and banks sometimes fail. If a financial intermediary were to fail and the securities available to that intermediary were insufficient to cover its customers' claims, the claims might not be satisfied. ${ }^{26}$ Investors with smaller portfolios controlled by registered broker-dealers can look to the Securities Investor Protection Corporation ("SIPC") or private insurance27 for protection. Investors not fully protected by SIPC generally select their intermediaries wisely. ${ }^{28}$

Current law deals with financial intermediary risk in a variety of ways. In addition to SIPC protection for some investors, financial intermediaries are regulated so as to make failures less likely and to make it more likely that there will be sufficient securities available for customer claims when an intermediary

24. For institutional investors such as insurance and investment companies, the financial intermediary normally will be a "custodian" bank, not the broker used to effect a trade in the market. See Mooney, 12 Cardozo L Rev at $324 \mathrm{n} 53$ (cited in note 5).

25. For example, a customer (C) might have a securities account with its financial intermediary broker (I-1), which controls securities for its customers (including $\mathrm{C}$ ) by maintaining an account as a customer of another, "upper-tier" financial intermediary (I-2). I-2, in turn, might control securities for its customers (including I-1) by maintaining an account as a customer of yet another "upper-tier" financial intermediary (I-3). I-3 might be a depository, such as DTC, I-2 might be a large national firm, and I-1 might be a smaller regional or local firm.

26. For a discussion of the treatment of customer claims in securities firm insolvency proceedings, see Michael E. Don \& Josephine Wang, Stockbroker Liquidations Under the Securities Investor Protection Act and Their Impact on Securities Transfers, 12 Cardozo L Rev 509, 527-47 (1990); Mooney, 12 Cardozo L Rev at 351-64 (cited in note 5).

27. Customers of broker-dealers registered under the Securities and Exchange Act of 1934 receive protection (analogous to deposit insurance) from SIPC against shortfalls in customer securities pursuant to the Securities Investor Protection Act of 1970 ("SIPA"), 15 USC $\$ \$ 78$ aaa 78111 (1988). When SIPA applies, a customer is entitled to advances from the SIPC fund of up to $\$ 500,000$ (although advances relating to claims for cash are limited to $\$ 100,000$ per customer). Id $\$ 78 \mathrm{fff}-3(\mathrm{a})$. Many securities firms provide additional privately issued insurance covering customer claims, often in the amount of $\$ 2.5$ million and sometimes in a greater amount $(\$ 10$ million, for example).

28. Customer losses in excess of SIPC coverage have been quite modest in the case of brokerdealer insolvency since SIPA became effective in 1971. See Mooney, 12 Cardozo L Rev at 325 n55 (cited in note 5). Losses on account of shortfalls in customer securities in bank failures, which are not covered by SIPA, have been virtually nonexistent. Id. 
does fail. ${ }^{29}$ Existing law dealing with the property rights of customers upon an intermediary's insolvency, however, does not provide complete protection for investors in the event of a shortfall. It does identify the nature and scope of the risks so that market participants can arrange their affairs and the systems accordingly. ${ }^{30}$

The next part of this article considers the impact of the attributes of information technology on commercial law in the contexts of the transfer of securities and clearance and settlement in the securities markets. The discussion also offers some more general insights concerning the creation, administration, and interpretation of laws and regulations in an environment dominated by information technology.

\section{III}

\section{LaW and Regulation: Applying the Taxonomy of Information Technology Attributes}

This part considers the attributes of information technology in four discrete but related contexts: (1) property law, (2) the legal regulation of systems and system participants, (3) assessing the application of technology and the market for systems, and (4) choices concerning the source and manner of legal regulation.

\section{A. Property Law}

Consider three means of transferring a property interest in investment securities under article 8 of the UCC: (1) physical delivery of certificated securities ("stone age transfer"), ${ }^{31}$ (2) book-entry registration of an interest in uncertificated securities on the books of the issuer ("registration bookentry"), ${ }^{32}$ and (3) book-entry transfer on the books of a financial intermediary that controls securities for the transferee ("intermediary book-entry"). ${ }^{33}$

29. Broker-dealers are subject to rules of the Securities and Exchange Commission ("SEC") dealing with the control and, in some cases, "segregation" of customer securities. See SEC Rule $15 c 3-3,17$ CFR $\$ 240.15 c 3-3$ (1991). Banks in the United States are subject to less elaborate rules but nevertheless are expected to maintain sufficient securities to cover all customer claims. See Mooney, 12 Cardozo L Rev at 327 n62 (cited in note 5). Both securities firms and banks are subject to elaborate regulatory and supervisory schemes. See id at 326-27.

30. See Mooney, 12 Cardozo L Rev at 313-15 (cited in note 5).

31. "Transfer of a security or a limited interest (including a security interest) therein to a purchaser occurs only: (a) at the time he or a person designated by him acquires possession of a certificated security." UCC $\$ 8-313(1)(a)$. Section 8-313(1) specifies an exclusive listing of the means by which a property interest in a security may be transferred to a purchaser. Article 8 securities are either "certificated" or "uncertificated." Id $\$ 8-102(i)(c)$. Certificated securities are "represented by an instrument," id $\$ 8-102(1)(a)$, whereas uncertificated securities are not represented by an instrument." Id $\S 8-102(1)(b)$.

32. Transfer of a security or a limited interest (including a security interest) therein to a purchaser occurs only "at the time the transfer, pledge, or release of an uncertificated security is registered to him or a person designated by him." Id \$ 8-313(1)(b).

33. Transfer of a security or a limited interest (including a security interest) therein to a purchaser occurs only:

(d) at the time a financial intermediary ... sends him confirmation of the purchase and also

by book entry or otherwise identifies as belonging to the purchaser 
Stone age transfer continues to occur, to be sure, but intermediary book-entry transfer of securities clearly represents the norm in the securities markets. The technology-enhanced systems for clearing and settlement have had much to do with this intermediary control phenomenon. Thus, the intermediary risk discussed above has become the norm as well. Connection of a securities claimant to the securities issuer by registration book-entry could, however, eliminate intermediary risk during the time period the registration remains effective.

1. Registration Book-Entry for Uncertificated Securities. The regime created for uncertificated securities pursuant to the 1977 revisions to article 8 is a dramatic example of a rare occurrence-statutory creation of a new genre of property, not yet in existence, accompanied by a corresponding new legal regime for that property. ${ }^{34}$ This approach was criticized, ${ }^{35}$ but the drafters' ("chicken-and-egg") response-that no one could issue, employ, or devise a system for uncertificated securities in the absence of a legal regime for themseems sound. ${ }^{36}$ Yet registration book-entry plays no meaningful role in today's securities markets; for all practical purposes, truly uncertificated securities are non-existent. Although uncertificated securities were seen as a response to the "paperwork crunch," 37 the depository system and information technology-aided methods of clearance and settlement basically solved that problem even before the revised article 8 was promulgated. Consequently, were uncertificated securities to become the norm, there would not necessarily be any material change in otherwise prevailing patterns of transfer and securities "holding," except that DTC would become the

(i) a specific certificated security in the financial intermediary's possession;

(ii) a quantity of securities that constitute or are part of a fungible bulk of certificated securities in the financial intermediary's possession or of uncertificated securities registered in the name of the financial intermediary; or

(iii) a quantity of securities that constitute or are part of a fungible bulk of securities shown on the account of the financial intermediary on the books of another financial intermediary.

Id $\S 8-313(1)$ (d). Transfers of "a specific certificated security;" pursuant to clause (i) are unusual in the securities markets, most intermediary book-entry transfers being transfers of interests in fungible bulks effected under clauses (ii) or (iii). See Mooney, 12 Cardozo L Rev at 370-71, 420 (cited in note 5).

34. For descriptions of the process leading to the 1977 article 8 revisions and the principal features of the revised article, see UCC app I at 925 (cited in note 4) (Reporter's Introductory Comment); Martin J. Aronstein, Robert Haydock, Jr. \& Donald A. Scott, Article 8 Is Ready, 93 Harv L. Rev 889 (1980).

35. See Peter F. Coogan, Security Interests in Investment Securities Under Revised Article 8 of the Uniform Commercial Code, 92 Harv L Rev 1013, 1073 (1979) (noting that there was no "hue and cry for uncertificated securities at the present time" and calling upon the drafters to reconsider the revised article 8).

36. Aronstein, Haydock \& Scott, 93 Harv L Rev at 913 (cited in note 34) ("The problem has all the aspects of the proverbial chicken-and-egg. The securities industry cannot intelligently design uncertificated systems until the rules have been established. And no one can be entirely confident that the rules are totally adequate until they are used.").

37. Id at 890 . 
registered owner of uncertificated securities instead of maintaining physical possession of certificated securities registered in its name. ${ }^{38}$

The fate of the uncertificated security exemplifies the impact on the lawmaking process of information technology's Frequent Change characteristic. Laws based on today's world may be inadequate or unresponsive to tomorrow's world, and the Frequent Change aspect of information technology exacerbates this problem. Moreover, in the context of uniform state laws such as the UCC, the excruciatingly slow process of drafting, promulgating, and enacting even makes prompt reaction to today's world problematic. Indeed, two states (plus the District of Columbia) have not yet enacted the revised article 8 , some fifteen years after promulgation! ${ }^{39}$

Were the enactment problems solved or materially reduced, another plausible perspective on uncertificated securities is more optimistic. Could the Storage Capacity, Transmission Speed, Ease of Access, Revision Speed, and Reduced Cost attributes of information technology be employed in a system where registration book-entry would be the norm but the efficiencies of current clearance and settlement systems would be maintained or even enhanced? If so, intermediary risk could be substantially reduced without the need for deliveries of certificated securities to and from investors.

Currently, customers who do not wish to allow an intermediary to control their securities may request that certificates be delivered to them. ${ }^{40}$ When a customer desires to sell those securities, however, the customer must deliver the certificates to a broker properly indorsed. ${ }^{41}$ That could present a serious problem for implementation of the G-30 recommendation that settlement (payment and delivery) occur on the third business day following the trade date $(T+3)$. After a move from a $T+5$ to a $T+3$ system, some retail customers might not be able to deliver in a timely fashion physical securities they have sold through brokers. ${ }^{42}$ One problem, then, is how to permit retail investors to eschew continuing intermediary control (and risk) while providing an efficient system for getting the securities in and out of the clearing and settlement system, which does require intermediary control on the settlement date.

38. Actually, securities controlled by DTC are registered in the name of a nominee partnership that it controls, Cede \& Co. See DTC 1991 Annual Report at 36 (cited in note 15).

39. Telephone conversation with John M. McCabe, Legislative Director, National Conference of Commissioners on Uniform State Laws (Aug 26, 1992).

40. Principal exceptions are U.S. treasury securities (all book-entry) and certain "book-entry only" municipal securities, the latter involving only one certificate that can be registered only to a securities depository, such as DTC. See DTC 1991 Annual Report at 26-27 (cited in note 15). In the case of U.S. treasury securities, customers can achieve the status of a registered owner of book-entry securities on the books of the government through the "Treasury Direct" system. See 31 CFR $\S \S 357.20$ - 357.32 (1991) (regulations governing the Treasury Direct system).

41. Also, the broker would either guarantee the customer's indorsement or require a bank signature guarantee. See note 44 .

42. It has been estimated that "approximately $90 \%$ of the securities sold by retail customers are in possession of their financial intermediaries by $\mathrm{T}+3$." Group of Thirty Clearance and Settlement Project, Status Report and Request for Comment 8 (U.S. Working Committee, 1990). 
Eliminating paper certificates and moving to a world of uncertificated securities would not, alone, solve this problem. If an investor were the registered owner on the issuer's books, the investor would have to give its broker an "instruction" to be delivered to the issuer or its transfer agent. ${ }^{43}$ Although instructions could be given electronically, that would be problematic for many retail customers unless new systems for giving instructions-such as instructions on automated teller machines ("ATMs")were employed.44 Alternatively, a selling customer could be required to deliver physical securities (or a written instruction in the case of uncertificated securities) to its broker as a condition to the broker's execution of a sell order for the securities. That approach would solve the problem, but it might be seen as an unacceptable restriction on the expected liquidity of marketable securities.

The G-30 U.S. Working Committee ${ }^{45}$ has considered a proposal that offers a plausible prospect for connecting retail investors with the registration books of issuers while also providing easy entrance to and exit from the clearing and settlement system. The proposed electronic communications system, called the Direct Registration Clearing System ("DRCS") might work as follows:46

(1) A purchasing investor could choose whether to have a conventional securities account with an intermediary (that is, intermediary control of a fungible bulk of securities) or to have its interest registered directly on the books of an issuer (that is, registration book-entry). ${ }^{47}$

(2) Street-side settlement of a trade made for a purchasing investor would occur in the DTC-NSCC system as it currently does. Immediately after settlement (on $\mathrm{T}+3$ ), the broker would effect customer-side settlement by causing the broker's DTC account (for

43. See UCC \$ 8-308(4) (defining "instruction" as "an order to the issuer of an uncertificated security requesting that the transfer, pledge, or release from pledge of the uncertificated security specified therein be registered"). Some issuers keep their own registration books and some use third-party transfer agents to keep the registration books. In the context of maintenance of the corporate registration books, "issuer" and "transfer agent" generally are used interchangeably to mean the entity responsible for keeping the issuer's books.

44. See UCC $\$ 8-308(5)$ (b) (providing that "[a]n instruction originated by an appropriate person" can be "a communication to the issuer in any form agreed upon in a writing signed by the issuer and an appropriate person"). Because of the duties and liabilities imposed on issuers and transfer agents, they ensure that indorsements and signatures pertaining to transfers of registered ownership are authorized and virtually always require signature guarantees by banks or brokers. See UCC $\$ \$ 8-401$ (duties of issuer to register a transfer) and 8-402(1)(a) (right of issuer to require a signature guarantee); Egon Guttman, Modern Securities Transfers 13-1 to 13-38 (Warren, Gorham \& Lamont, 1987) (discussing signature guarantees).

45. The U.S. Working Committee is a private group organized by securities industry participants to address implementation of the G-30 Report in the U.S. markets.

46. A possible model for DRCS has been outlined by the U.S. Working Committee. Group of Thirty Clearance \& Settlement Project, Implementing The Group of Thirty Recommendations in the United States VI-19 to VI-45 (U.S. Working Committee, 1990) ("G-30, Implementing the Group of Thirty Recommendations"). The following description generally follows that model, although much detail is omitted here.

47. The system contemplates that the securities would be uncertificated, but it could coexist with a system that also allows investors to have the option of receiving paper, certificated securities. 
the securities issue involved) to be debited and the DTC account of the transfer agent for the issuer to be credited by a quantity corresponding to the investor's purchase. ${ }^{48}$ The broker also would give instructions through DRCS that would result in the broker's account on the transfer agent's books being debited and the investor being credited with the securities on the transfer agent's (that is, issuer's) books. An article 8 initial transaction statement would be sent to the investor. ${ }^{49}$

(3) A selling investor would contact its broker and request the sale. The broker, through DRCS, would confirm with the transfer agent that the investor is the registered owner of the securities to be sold. If the securities were there, a "lock" would be put on the quantity involved and the investor could not deal with those securities thereafter.

(4) On the settlement date $(T+3)$, the transfer agent would debit the investor's account and credit the broker on the transfer agent's books. The transfer agent then would instruct DTC to debit its account on DTC's books and credit the broker's account. The securities would be "in the system" so that the broker could "deliver" them in settlement of the trade.

There remains another problem with DRCS that would have to be resolved. How would the selling investor give the broker the authority to act for the investor in communicating with the transfer agent? If the investor must deliver a written instruction, then the system has not accomplished its goals. And if the investor gives the broker a blanket pre-authorization to act for it, then much of the intermediary risk would remain. ${ }^{50}$

Current technology could solve this problem of how the investor would put its securities back into the system. For example, the market could employ a system similar to the message authentication code developed by the Bank of Japan ("BOJ") for its newly automated registration system for Japanese government bonds. ${ }^{51}$ Applied to DRCS, the system might work like this: The

48. Each transfer agent, including issuers acting for themselves, would have a special account with DTC for this purpose.

49. See UCC $\$ \S 8-408$ (1) - (4) (requiring issuer to send an "initial transaction statement" within two business days after registration of a transfer and requiring the initial transaction statement to be "a written statement" that is "signed by or on behalf of the issuer"). Although an "instruction" may be given in a non-written form, an initial transaction statement must be in writing. Id; see note 44. The ABA Interim Report calls for amendments to UCC \$\$ 1-201(46) (defining "written" and "writing") and 8-408 so as to embrace electronic communication. ABA Interim Report at 46-47 (cited in note 5 ).

50. If the broker had been given a blanket pre-authorization to act for the investor, then the investor's claim would be treated the same way as a conventional securities account in the broker's insolvency proceeding - that is, the customer would not be given a direct claim against the securities but would share with other customers in the pool of "customer property." See Mooney, 12 Cardozo $L$ Rev at 352-54 (cited in note 5). With pre-authorization, the desired risk reduction benefits of direct registration would not, therefore, be available under current law.

51. The system devised by the Bank of Japan ("BOJ") is used to authenticate a buyer's agreement to receive a transfer. However, it could just as well be employed to authenticate a seller's wishes. A brief description of the system follows: 
investor would contact DRCS by telephone or ATM. By use of a personal identification number ("PIN") and standardized identification codes, the customer would indicate the securities issue and the quantity to be sold. DRCS would then give the customer a transaction code that would be matched to the trade in DRCS. The investor would give this number to its broker when placing the sell order. When executing the sell order, the broker would use the number given by DRCS to the customer. DRCS and the transfer agent would then know that the broker is authorized to make the specific trade for the selling investor. DRCS would thereby utilize the Centralization attribute of information technology by employing a centralized communications network with remote user access.

What would the emergence of a system like DRCS (or any other system grounded on uncertificated securities) indicate about the approach taken by the drafters of the 1977 revisions to article 8 ? Would it prove that they were enormously prescient? I have found nothing specific in the drafting history or contemporary literature that indicates that the drafters had any specific conceptualization of how uncertificated securities would reduce the movement of paper generally, as opposed to the movement of certificated securities. Consequently, one could claim that the eventual use of uncertificated securities in such a system would be merely a lucky break. I would offer a different view that is of more general applicability. By creating a framework for uncertificated securities, and by unburdening the legal regime from its dependence on certificated securities, the revised article 8 has provided an opportunity for those who might create different systems for trading, clearing, and settling. Perhaps it did not go far enough, but the idea was and is sound.

There are some more general lessons here for law makers. The Unpredictability attribute of information technology must be acknowledged, but it need not be paralyzing. For example, the writers of statutes and regulations should develop a paper-neutral approach. The case at hand, a system of property law for paperless intangibles, can be imagined as one where someone is keeping an electronic scoreboard that matches owners with

The securities-wire system will require a registration transfer order from only one party (the seller), while the current regulation requires orders from both the seller and the buyer. Thus, the new system will employ a message authentication code (MAC) to verify the intention of transfer of the other party (the buyer). MAC will be formulated by combining the transaction data with a secret key utilizing a special algorithm. The MAC message will be tamperproof unless the key is known. The system will work in the following manner: (1) BOJ provides participants with a MAC key beforehand, (2) when a transaction is made, the buyer formulates the MAC $(f(a, x))$ on the basis of the key (a) and the transaction data $(x)$, and transmits it to the seller, (3) the seller then inputs data $(x)$ and the MAC $f(a, x)$ into BOJNET [the BOJ's computer network for transferring funds and Japanese government securities], (4) BOJ checks that the MAC [is] formulated according to the buyer's key (a) and the transaction data $(x)$ input by the seller. Authenticity of the seller's intention is confirmed by checking the information on the ID Cards [required for communicating in BOJ-NET] of the [seller's] authorized officers, etc. After verification, BOJ processes the registration transfer.

Payment System Project Team, Outline of Bank of Japan Financial Network System (BOJ-NET) 21 22 (The Bank of Japan, 1989). 
property. ${ }^{52}$ In registration book-entry, it is the issuers of securities (or their transfer agents) that maintain the records of the securities owners. As to how the scoreboard is turned on and off and how the scores are recorded, the law should say as little as possible. Imagine that a securities owner could electronically "dip into" the issuer's records in order to "see" the owner's recorded interest. Or imagine that the owner's broker were to confirm that the owner's interest was recorded by the issuer. In either case, initial transaction statements from the issuer to the owner, even if electronically communicated, might not be necessary. Perhaps, to the greatest extent possible, statutory property law should omit as many of the details of how interests are recorded and unrecorded, leaving the detail to more easilyadjusted administrative regulation of financial intermediaries or markets or both.

2. Intermediary Book-Entry for Certificated and Uncertificated Securities. Some of the concluding observations in the previous section also are applicable in the context of transfers of interests in fungible bulks of securities by financial intermediaries to their customers through intermediary book-entry. In this case, the financial intermediary is maintaining the scoreboard for its customers. Elsewhere, I have criticized the statutory language that deals with intermediary book-entry transfers-UCC sections 8-313(1)(d)(ii) and (iii). ${ }^{53}$ On a more basic level, I have challenged the property construct in article 8 , which requires the statute reader to imagine that a customer of a financial intermediary has a conventional property interest in a fungible bulk of securities, and I have argued that in the fungible bulk context, approaches such as tracing and first-in-time priority rules are inappropriate. ${ }^{54}$ Even under current law, what a customer receives upon an intermediary book-entry transfer essentially is merely a claim against the intermediary-a claim that bears little resemblance to a conventional property interest in securities. ${ }^{55}$ If the intermediary does not fail, the customer receives the benefit of the securities that are "in" the customer's account. If the intermediary fails, the customer receives its entitlement under applicable insolvency law.

Information technology has played a key role in the modern systems for clearance and settlement that have led in large part to the prevailing dominance of intermediary control in the marketplace. At the present time, however, the existence of, location of, and value of securities controlled by an intermediary and the means by which that intermediary controls securities are invisible to customers claiming through that financial intermediary. As discussed in the previous section, information technology easily could be

52. I have borrowed this imagery from Professor Rogers. See James Steven Rogers, Negotiability, Property, and Identity, 12 Cardozo L Rev 471, 504-05 (1990).

53. See Mooney, 12 Cardozo $L$ Rev at 331-42, 425-27 (cited in note 5).

54. Id at 349-51, 365-97. The 1992 draft of article 8 adequately responds to my critique; it adopts the substance of each of my principal proposals for reform.

55. This effect of intermediary book-entry can be contrasted with registration book-entry, in which case the transferee receives a direct claim against the issuer of the securities. 
employed to disconnect the customers from financial intermediaries and to connect them to issuers. Also, it could be used to connect customer claims to some sort of centralized scoreboard ("centralized book-entry"), instead of registration book-entry on the issuer's books, where the customers' discrete claims could be recorded. For example, investor claims could be reflected on the books of DTC at the end of each day, even though the investors would not be direct participants in the NSCC-DTC street-side system for securities and funds settlement. ${ }^{56}$ Alternatively, the central system could be operated by a government, just as governments now operate filing and recording systems. Direct investor communications with the central scoreboard, as discussed in connection with the DRCS proposal, could be devised. In effect, these systems would substitute a presumably less risky central intermediary, itself connected to the various securities issuers, for the intermediary with which the investor otherwise would have a securities account.

A system like DRCS or a centralized book-entry system might or might not provide aggregate net benefits when compared with other alternatives, including the current systems. And either could be achieved with little or no change in law. Certainly it is not the absence of adequate technology that stands in the way. Instead, it is the fact that the interested parties have not seen fit to make such fundamental changes.

3. Security Systems, Privacy, and Breakdown. The Ease of Access and Speed of Access attributes of information technology pose challenges to those charged with keeping systems secure and free from unauthorized tampering. ${ }^{7}$ Although these concerns are in no way peculiar to systems that keep track of property rights, certainly the significance of maintaining the integrity of these systems is self-evident. In addition, the Storage Capacity and Transmission

56. A similar approach would be employed by a new product under consideration by Midwest Securities Trust Company ("MSTC"), a securities depository. That product-called an "individual Safekeeping Account"-would permit individual, retail customers to have special accounts with MSTC. See Midwest Securities Trust Company, Individual Safekeeping Account, A Report for U.S. Working Committee-Group of Thirty Clearance and Settlement Project, DRS Industry Participant Subgroup (Midwest Securities Trust Co., 1991). The product's operation would be similar to the DRCS system sketched out above, except that investors would end up with credits in securities accounts with MSTC instead of direct registration on the books of the issuer.

The TAURUS system in the United Kingdom, which has not yet been made operational, illustrates another alternative. That system would involve shareholder accounts with regulated "controllers"-either a "company controller" (somewhat analogous to a transfer agent) or a "commercial controller." Periodically, each issuing company's registration books would be updated to reflect shareholder interests as reflected on the books of controllers. However, the controllers would have "entitlements" for all of the shares that they control for shareholders. The entitlements would enable the controllers to transfer registered ownership of those shares on an issuing company's books. In that respect, the system bears some resemblance to DRCS coupled with a preauthorization given to an investor's financial intermediary. For an overview of the TAURUS system, see The Uncertificated Securities Regulations, A Consultative Document Part I (Dept of Trade and Industry, 1990). Part III of that document contains the draft regulations, and Part II contains a summary of each provision of the draft regulations.

57. See Edwin M. Cortez \& Edward John Kazlauskas, Managing Information Systems \& Technologies 89-91, 104-05 (Neal-Schuman, 1986) (discussing various methods of protecting access to data processing systems) ("[A]ny facility must safeguard its operation against people-caused problems such as theft, human error or ignorance, and malicious mischief." Id at 104.). 
Capacity characteristics heighten the risks of unwanted interference. These characteristics also raise the stakes for those who wish to keep their affairs private. ${ }^{58}$

The stakes of the present securities system are also high when the prospects of a system participant default or a system breakdown are considered. The interdependence of financial intermediaries in the process of clearance and settlement of securities and funds transactions offers the prospect of systemic risk of multiple defaults in the event of a system participant's insolvency or illiquidity. ${ }^{59}$ Similar risks are posed by the possibility of a breakdown of technological applications, and the System Complexity and Technology Complexity attributes make these risks real. ${ }^{60}$

\section{B. Regulation of Systems and Systems for Regulation}

The securities markets and many professional market participants are regulated by the Securities and Exchange Commission ("SEC"), principally under the authority of the Securities and Exchange Act of 1934. Of particular

\section{As Ethan Katsh has noted:}

Instances of loss of privacy or problems in enforcement of privacy laws are part of a general difficulty in controlling information. What the difficulties now being experienced by the copyright, obscenity, and privacy laws suggest is that any institution in the new communications environment will find it difficult to keep a firm hold on proprietary information. Both individuals and governments are learning that a central feature of electronic information is that it is in motion as often as it is stationary. Each time such information moves, it is subject to copying, editing, and revising. Exclusive control of information and the power associated with that control is, therefore, difficult to achieve not only by individuals but by governments as well.

Katsh, The Electronic Media and the Transformation of Law at 194 (cited in note 8). See also U.S. Congress, Federal Government Information Technology: Electronic Record Systems and Individual Privacy (Govt Printing Office, 1986) (OTA-CIT-296).

59. See, for example, Systemic Risks in Securities Markets 31-38 (Organisation for Economic Cooperation \& Development, 1991).

60. Marcia Stigum's colorful description of two "computer snafus," involving two clearing banks in the government securities market, is illustrative.

Irving's snafu. One fine day a clerk set a switch on an Irving Bank computer so that instructions that were supposed to go out over the Fed wire were all written to disk instead ... . "We were," said an ex-Irving officer, "acting as a kind of black hole for securities."

"Around 3:15 p.m., just after the Fed wire closed, we discovered that we had, thanks to our mis-set computer switch, a problem: we had not received $\$ 4$ billion of funds that we thought we had ...."

"We became a black hole for funds. No offer rate [in the funds market] was too high for us. Finally, ... we had bought everything there was; ... . At that point, we still had about 1.7 billion to go. To get that, we had to go to the Fed ...."

Computer errors can be costly. Interest on $\$ 1.7$ billion, even on an over-night borrowing, is bound to amount to a tidy sum.

BONY's snafu. ... BONY [Bank of New York] pulled a boner that caused the Irving OD [overdraft] to pale in significance. On a November Thursday in 1985, BONY was preparing to change software in its computer system when trouble hit: BONY could accept deliveries of securities, but it couldn't make them. BONY's technicians took almost 28 hours to clean up that malfunction; during that time, deliveries and payments in the market for Treasuries came to a near standstill. . . . BONY had to borrow $\$ 22$ billion from the [Federal Reserve Bank of New York]. That borrowing, said to be the largest ever from the discount window, cost BONY $\$ 5$ million and a bit of embarrassment.

Marcia Stigum, After the Trade: Dealer and Clearing Bank Operations in Money Market and Government Securities 117 (Dow Jones-Irwin, 1988). 
interest here is the fact that the SEC regulates "clearing agencies" such as DTC and NSCC.61 In connection with issuing orders approving the registration of clearing agencies, the SEC reviews in detail the operational aspects of proposed systems for clearing and settlement such as NSCC's CNS system. ${ }^{62}$

\section{Regulators must overcome System Complexity and Technology} Complexity if they are adequately to understand and assess the risks and relationships that inhere in operational systems. This regulation and supervision requires much more than reviewing and analyzing financial statement-like reports and data. It often requires playing out "what if" scenarios, such as those posed by the possibility of financial institution insolvency and illiquidity.

Surprisingly, information technology seems to have had remarkably little impact on the basic approach of the SEC's regulation and supervision. Although a general critique of financial institution regulation is not within the scope of this article, it may be worth asking whether information technology could provide a new model for regulation and supervision. In lieu of traditional approaches such as notice and reporting requirements, spot audits, and the like, 63 one can imagine a financial intermediary as a patient in a hospital's intensive care ward (an apt and easy bit of imagery in the case of some financial institutions). Electronic "nodes" would be attached to all of the financial intermediary's "vital organs." The regulators would monitor the intermediary's "vital signs" on a "real time" basis. They could immediately (or almost immediately) discover changes (such as withdrawals of capital or shortfalls of customer securities). Indeed, the complete financial condition of the intermediary would be continuously exposed.

61. Clearing agencies are required to be registered under $\S 17 \mathrm{~A}$ of the Securities Exchange Act of 1934. 15 USC $\S 78 \mathrm{q}-1$ (b) (1988).

62. See Exchange Act Rel No 20,221, 48 Fed Reg 45167-8 (Oct 3, 1983) (ordering registration of DTC, NSCC, and several other entities as full clearing agencies).

63. As to the limitations of current techniques, consider some events preceding the bankruptcy of Drexel, Burnham, Lambert Group Inc. ("Group"), the parent of Drexel, Burnham, Lambert, Inc. ("DBL"), a registered broker-dealer. During January 1990, without notifying the SEC or the NYSE, Group withdrew approximately $50 \%$ of DBL's excess capital in order to meet a liquidity crisis in servicing Group's short-term unsecured debt. Registered broker-dealers are required to maintain certain minimum net capital. See Guttman, Modern Securities Transfers at 19-11 to 19-20 (cited in note 44) (discussing reporting and net capital requirements for broker-dealers). Concerning the Group and DBL financial problems, see The Issues Surrounding the Collapse of Drexel Burnham Lambert, Hearings before the Senate Committee on Banking, Housing and Urban Affairs, 101st Cong, 2d Sess 7 (1990) (statement of Richard C. Breeden, SEC Chairman). As Group's crisis grew worse, the SEC became aware of the problems. On February 7, 1990, the SEC notified Group and DBL in writing that further depletion of DBL's capital would not be permitted except with prior notice to and approval by the SEC and the NYSE. Id. On February 12, the NYSE (in consultation with the SEC) denied approval for an additional withdrawal from DBL's capital because the prospects for Group's solution of its liquidity problems had become poor. Id at 41-42. After the markets closed on February 13, Group filed a petition for relief under Chapter 11 of the Bankruptcy Code. Id at 44-46. SEC Chairman Breeden has placed some blame for the SEC's surprise on the SEC's lack of supervisory control over broker-dealers' holding companies, such as Group. However, the SEC does have supervisory power over broker-dealers such as DBL, but for a period of time the SEC was not aware of the material withdrawals of DBL's capital. 
A continuous electronic monitoring of financial intermediaries might allow regulators to make it less likely that financial intermediaries would fail and less likely that a shortfall in customer securities would occur were a failure to occur. This "tripwire" approach would address the most significant manifestations of insolvencies and financial distress in recent years-the health of the financial institutions on which the world's economies depend for a vast array of services and credit.

\section{Assessing the Application of Technology and the Market for Systems}

The Frequent Change characteristic of information technology does not ensure that systems representing optimal applications of technology will actually occur. Conversely, the fact that a problem can be addressed by the application of an information technology system does not necessarily mean that it is appropriate to apply that system. The DRCS proposal is illustrative.

The principal proponents of DRCS within the G-30 U.S. Working Committee have been the transfer agents and issuers. ${ }^{64} \mathrm{~A}$ review of the materials generated to date indicates that their support may be grounded largely on perceived self-interest that is unrelated to solving the problem of achieving $T+3$. The transfer agents apparently see direct registration through special transfer agent accounts with DTC as a means to entrench and even enhance their roles in the market. ${ }^{65}$ The issuers see DRCS as leading to more direct registration and less fungible bulk intermediary control, thereby

64. The statement in the text and some of the statements that follow reflect my conclusions and impressions based on numerous conversations with interested persons and my attendance at meetings of the U.S. Working Committee's Legal and Regulatory Subgroup, on which I serve.

65. See G-30, Implementing the Group of Thirty Recommendations at VI-19 (cited in note 46) ("The Direct Registration Concept . . embraces an approach building upon a solid foundation of current practices, procedures and technology. Many of the infrastructures for direct registration statement record keeping exist and are well accepted and understood by investors and the transfer industry."). DTC has expressed less enthusiasm:

Analysis of earlier versions of DRCS considered since the late 1960's shows why "that dog won't hunt." It founders on the fact of the heavy automation investment it would require of almost 2,000 corporate and municipal transfer agents, most of them small, since those agents would have to communicate interactively with financial intermediaries and DTC. Add to that the unknown large cost of linking brokers' offices in a computerized network reaching all transfer agents to confirm the securities positions of customers placing sell orders.

Memorandum from The Depository Trust Company to its Participants, The Group of Thirty (Nov 20,1990 ). If the DTC assessment is accurate, perhaps it is primarily the more substantial transfer agents that would stand to gain a competitive edge from DRCS. It also is reasonable to assume that there would be more in and out entries on the transfer agents' books in a DRCS system, and, consequently, the potential for more fees. 
revealing the identities of more of their shareholders. ${ }^{66}$ These positions are clear examples of what Wiseman calls "offensive strategic thrusts." 67

The principal opponents of DRCS within the G-30 U.S. Working Group seem to be DTC and the securities firms. For this reason, it now seems unlikely that DRCS (at least in something like its present configuration) will be implemented. The securities firms apparently fear, probably with good reason, that DRCS will result in their losing customer accounts and customer loyalty in executing trades. ${ }^{68}$

It appears that the SEC will not encourage or impose a system like DRCS, but instead will be content to let the market participants determine if and when to implement such a system. ${ }^{69}$ Even if something like DRCS would be more efficient than current practices, it does not follow that the market would be responsive, especially in the face of securities firm opposition. It may be that high-volume, high-value institutional investors are not sufficiently dissatisfied to insist on any change. And other retail investors might not overcome the collective action problems that would impede efforts to influence change. If material changes are to occur in the clearance and settlement systems and the securities-holding practices of investors in the United States, chances are that they will be inspired by competition from other markets (such as Japan and Europe)..$^{70}$

\section{One report concluded that}

DRCS will benefit corporate issuers by preserving and potentially increasing the number of directly registered investor accounts. With direct corporate communication to investors, it is reasonable to expect that corporate communication, proxy distribution, tabulation and reporting could be accomplished faster, more efficiently and more economically than at present.

G-30, Implementing the Group of Thirty Recommendations at VI-20 (cited in note 46). Of course, if it is a good thing to create a communications system between issuers and their securities holders, that could be done without the system constituting an ownership registry. Not satisfied, the report continues with the following, rather amazing, hyperbolic non sequitur:

Increased investor participation and a direct link to the corporate issuer should result in a greater sense of loyalty to the issuer, especially in times of crisis. This is seen as a means to Id.

help bolster faith in the market and the American economy.

67. See Charles Wiseman, Strategy and Computers: Information Systems as Competitive Weapons 42-57 (Dow Jones-Irwin, 1985). In an "offensive strategic thrust," an organization applies information technology not merely to automate or make more efficient the activities of its business, but to acquire a substantially larger market share or otherwise to enhance its position.

68. See G-30, Implementing the Group of Thirty Recommendations at VI-22 (cited in note 46) (listing goals of DRCS as including "portability of securities among broker/dealers and financial intermediaries").

69. A portion of SEC Commissioner Mary L. Schapiro's remarks before a conference of the Securities Industry Association has been summarized and quoted as follows:

[A] mechanism that would allow easy transfer, but provide necessary safeguards against fraud, has not yet been perfected. Nor has the Working Committee identified an industry group that is willing to "foot the bill for building and operating a direct registration system." The Commission, opined Ms. Schapiro, would like to see a workable direct registration system developed, but she added that the initiative for developing such a system

"rests squarely on the shoulders of private industry."

Fed Secur L Rptr (CCH) 5 (No 1428, Jan 2, 1991).

70. See OTA, Trading Around the Clock at 78-79 (cited in note 1) (discussing U.S. leadership in harmonization of operational and regulatory schemes). 
Notwithstanding the intuitive appeal of DRCS, ${ }^{71}$ moving to a DRCS-like system might be inefficient and unwise nonetheless. The process of assessing technological change, although continuously evolving, has become an increasingly important and sophisticated discipline. ${ }^{72}$ Much has been written about the risks of technological developments. Some, such as adherents to the "Appropriate Technology" movement, have questioned the wisdom (efficiency) of introducing advanced technology in certain societies and contexts where they believe it may do more harm than good. ${ }^{73}$ Others have dwelled on technological developments (such as nuclear energy) that are perceived as potentially dangerous to our health. ${ }^{74}$ By way of analogy, assessing information technology in the present context involves considering whether the current system, a DRCS-like system, or some other system would be more or less dangerous to our wealth. ${ }^{75}$

A critique of the proposed DRCS system cannot be accommodated here, but it may be helpful to identify some of the costs and benefits of such a system.

(1) Second-Guessing $T+3$. Although shortening the time between trade date and settlement tends to decrease aggregate risk, it does not follow that the costs of imposing $T+3$ (including the implementation of DRCS) necessarily justify this reduction of risk.

71. The most straightforward argument in support of adopting a DRCS-like system goes something like the following: Moving to $T+3$ will reduce risk. Some selling retail customers cannot/would not get their certificates in the system in time for $T+3$. It is a bad idea to force retail investors to allow intermediaries to control their securities because the investors' perceptions of intermediary risk may cause some of them to flee the market. Therefore, it is necessary to find a way to shelter investors from intermediary control and risk, and to eliminate securities certificates, while making it easy for investors to get their securities into and out of the intermediary system necessary for clearing and settlement. DRCS could do this. It follows that something like DRCS should be adopted.

I do not intend to suggest that the absence of something like DRCS is the only impediment to changing the settlement day from $T+5$ to $T+3$. Not only is shortening the time between a trade and a "delivery" problematic, but shortening the time between a trade and payment by the buyer also has substantial market implications.

72. See generally, for example, Cortez \& Kazlauskas, Managing Information Systems Eْ Technologies (cited in note 57); Janet Fulk \& Charles Steinfield, eds, Organizations and Communication Technology (Sage, 1990); Norbert Szyperski, et al, eds, Assessing the Impacts of Information Technology (Vieweg, 1983). The United States Congress has recognized the importance of rigorous examinations of technology applications by establishing its Office of Technology Assessment. See 2 USC $\S \S 471,472$ (1988).

73. For a thorough survey and critique of the literature, see Kelvin W. Willoughby, Technology Choice: A Critique of the Appropriate Technology Movement (Westview Press, 1990). The origins of the Appropriate Technology movement are found in the writings of Ernst Friedrich Schumacher about what he called "intermediate technology." Id at 55-97.

74. See, for example, Clayton P. Gillette \& James E. Krier, Risk, Courts, and Agencies, 138 U Pa L Rev 1027 (1990); James E. Krier \& Clayton P. Gillette, The Un-Easy Case for Technological Optimism, 84 Mich L Rev 405 (1985).

75. For recent examples of assessments of the application of technology in the financial markets, see generally OTA, Effects of Information Technology on Financial Services Systems (Govt Printing Office, Sept 1984) (OTA-CIT-202); Henry C. Lucas, Jr. \& Robert A. Schwartz, eds, The Challenge of Information Technology for the Securities Markets (Dow Jones-Irwin, 1989); Saunders \& White, eds, Technology and the Regulation of Financial Markets (cited in note 11); Siegel, ed, Innovation and Technology in the Markets (cited in note 11 ). 
For example, no effort seems to have been made to quantify the actual reduction of risk that $\mathrm{T}+3$ could provide. ${ }^{76}$

(2) Assumptions and Information About Retail Investors. The DRCS proposal is based on several explicit and implicit assumptions about retail investors, none of which appear to have been subjected to sufficiently close scrutiny. ${ }^{77}$

(3) Costs and Benefits of Creating and Operating a New System. Because DRCS would be accessible to retail investors it would seem to follow that it would be even more friendly to active wholesale market participants. Presumably institutional investors would consider taking advantage of daily registration on the books of issuers' transfer agents. If this were so, then the system could not be viewed as a limited one applicable only to risk-averse retail investors. It would involve the creation and implementation of a fundamentally changed market system. Moreover, by adding additional steps to many transactions, the operating costs could be increased. Would the costs outweigh the benefits? ${ }^{78}$ Who would bear the implementation costs and, if any, increased operational costs? It is unlikely that these costs would be borne only by the retail investors who (presumably) would otherwise flee the market. ${ }^{79}$

76. See Madhavan, Mendelson \& Peake, $3 \mathrm{~J}$ Intl Sec Mkts at 11 (cited in note 22) (describing a model that "can be used to develop quantitative estimates of the impact of a change in the settlement period").

77. The Direct Registration Subcommittee of the U.S. Working Committee did conduct an "investor sentiment survey" of 362 randomly selected holders of physical certificates and directly registered dividend reinvestment plan shareholders. G-30, Implementing the Group of Thirty Recommendations at VI-9 to VI-18 (cited in note 46). Although that survey does provide some insight into the preferences of these investors, it provides little or no insight as to some important assumptions. For example:

(1) Retail investors who now choose to hold physical certificates would leave the market if certificates were eliminated and investor choices were reduced to either (i) holding through conventional securities accounts, or (ii) delivering paper instructions to their broker before placing sell orders. The latter alternative might reduce the number of trades, thereby costing brokers some commissions.

(2) Either (i) there would be a material, adverse effect on the market and its participants arising out of the decisions of retail investors to flee the market, given those choices, or (ii) it would not be feasible politically to limit investors to those choices.

(3) Retail investors who now hold certificates generally would be satisfied with, and use, a system like DRCS.

None of these assumptions seems plausible, much less compelling. For example, a profile of the prototype "paper holder" might reveal a natural person who does not own a PC, does not use ATMs, and, perhaps, does not even believe in the radio! Would that investor be willing to sell securities by using the telephone to get a magic number? Would that investor be satisfied if she were given the option to continue holding paper securities, provided that she could not place a sell order for the securities before making an actual delivery of the certificates to a broker?

78. The DRCS proposal addresses how to reach $\mathbf{T}+3$ without disrupting retail investor behavior patterns. It was not originally motivated by a general concern that intermediary risk, and therefore intermediary control, must be reduced in any event.

79. Note that the $T+3$ proposal (and the other $G-30$ proposals) originated with the largest players in the securities and banking industries. That is comforting in one sense; these players are likely to be informed and, perhaps, not likely to make proposals that would adversely affect the market. On the other hand, because costs might be passed on to other market participants in a way that would not affect the competitive balance within and between the securities and banking 
Smaller, "lower tier" intermediaries who do not have direct relationships with DTC might be disadvantaged by a DRCS system unless DRCS were to make provision for automated direct registration of the interests of these lower tier intermediaries' customers. That approach would necessitate additional steps and complexity.

Would DRCS provide meaningful risk reduction? Arguably the principal risks imposed by financial intermediary control of securities are those involving default in the clearance and settlement process, not those regarding fungible bulks already controlled for beneficial owner/customers. ${ }^{80}$ The clearance and settlement risks would not be reduced by DRCS because securities and payments would be "in the system" pending "street side" settlement among intermediaries and "customer side" settlement consisting of transfers or payments to customers. ${ }^{81}$

(4) Additional Costs Resulting From the Reduction of Intermediary Control. A system that would result in widespread and routine end-of-day registration on issuers' books could impose costs other than the direct costs of implementation and operation. For example:

(a) Reduced Monitoring. Those who select intermediaries to control their securities generally have exercised care and have been successful. Securities customer losses from intermediary failure have been infrequent and generally not large. ${ }^{82}$ If imposing a system like DRCS were to result in a world where most securities customers are not exposed to intermediary risk (except pending settlement), careful selection and monitoring might be reduced. Although small investors are protected by SIPC and private insurance, ${ }^{83}$ investors with large accounts are not. Many observers have noted the "moral hazard" problem imposed by analogous deposit insurance for banks and have attributed, at least in part, financial institution insolvencies to that problem. ${ }^{84}$ If neither large nor small investors engaged in monitoring (that is, if relatively little risk were associated with the selection of an intermediary), arguably intermediaries would engage in riskier behavior. Nonetheless, it seems probable that the combination of

industries, there is no assurance that proposals from those industries inevitably will be efficient and fair.

80. See text accompanying notes $20-21$.

81. Keep in mind that the big players have managed intermediary risk well and the small players are covered by the Securities Investor Protection Corporation (SIPC) and private insurance. See text accompanying notes $26-30$.

82. See note 28. During the last twenty years, the principal exceptions to the statement in the text involved the failures during the mid-1980s of several then-unregulated government securities dealers. See Mooney, 12 Cardozo L Rev at 328 n65 (cited in note 5).

83. See note 27.

84. See, for example, Jonathan R. Macey \& Elizabeth H. Garrett, Market Discipline by Depositors: A Summary of the Theoretical and Empirical Arguments, 5 Yale J Reg 215, 223-39 (1988). 
regulation and supervision and monitoring by creditors who are not securities customers would substantially offset any reduced monitoring.

(b) Disparate Treatment. Imposition and widespread selection of record ownership through DRCS (that is, if DRCS were selected by a materially greater proportion of securities claimants than the proportion who now hold certificates) could result in highly disparate treatment of securities claimants in the event of an intermediary insolvency. Most of the securities claimants not in the DRCS system might turn out to be those who had transferred securities to an intermediary for sale or who had already paid an intermediary for securities to be transferred (that is, those whose transactions were pending settlement) and those who had maintained ordinary securities accounts primarily to maintain privacy (that is, those who do not wish the issuer to know their identity). The intermediary's insolvency would expose only those investors and not others.

Inasmuch as more investors would be freed from risk and losses would be smaller under an DRCS scheme, that scheme would provide the intended benefits of reduced risk. But the distributional schemes in the Bankruptcy Code and under SIPA contemplate that most customers will leave their intermediary in control of securities. ${ }^{85}$ Were a much smaller proportion of the investors exposed to intermediary risk, it might be necessary to rethink distributional schemes designed in large part to operate in a market where intermediary control is the norm.

(c) Increased Securities Borrowing. Current regulations allow brokers to experience temporary shortfalls in customer securities occasioned by failed trades (that is, someone fails to deliver). ${ }^{86}$ Were DRCS direct registration the norm, it could result in increased securities borrowing by brokers in order to meet street-side settlement obligations. ${ }^{87}$ That, in turn, would result in additional credit risk for securities

85. See note 50 .

86. See SEC Rule 15c3-3(b)(2), 17 CFR $\$ 240.15 c 3-3(b)(2)$ (1988) ("temporary lags" in obtaining possession or control of securities are permitted if they result from "normal business operations" and the "broker or dealer takes timely steps in good faith to establish prompt physical possession or control").

87. A securities borrowing transaction in this context might look something like this: Broker A is short on X Company securities needed to satisfy its net settlement obligation. Broker $A$ borrows the X Company securities from Broker B and promises to "repay" the loan with a like quantity of X Company securities on a day certain. Broker A gives to Broker $\mathbf{B}$ a quantity of $\mathrm{Y}$ Company securities (normally of a slightly higher value than the borrowed X Company securities) as collateral for Broker A's "repayment" obligation. Broker B earns a fee in the transaction. See David M. Weiss, After the Trade is Made 364 (New York Inst Finance, 1986); see also Stigum, After the Trade at 204-05 (cited in note 60) (describing securities borrowing in the government securities markets). 
lenders and additional expenses incurred by securities borrowers.

(d) Countervailing Market Behavior. Although superficially worrisome, all of these additional, indirect costs would likely be overcome by market behavior. For example, although less monitoring would occur, it probably would occur at an appropriate level. Disparate treatment of market participants would be based on ex ante choices made by those participants, presumably made with their own interests in mind. And securities would be borrowed only if that activity were more efficient than the alternatives.

(5) Other Alternatives for Reducing Intermediary Risk. Comparing the hypothetical world of DRCS with the existing system does not take into account other, possibly more efficient and effective means of reducing intermediary risk. The use of information technology for enhanced regulation and supervision, discussed above, is an example.

Existing technology could create and sustain something such as DRCS that routinely would connect investors with issuers, thereby removing their securities from fungible bulks controlled by intermediaries and reducing intermediary risk. Reasonably accurate estimates of the direct costs of implementing and operating the system probably could be made. Nevertheless, it is enormously difficult to justify those costs. Predictions of investor attitudes and behavior, the benefits of moving to $T+3$, and the indirect costs that would be imposed by the system are problematic. The proponents of the system do not seem to have addressed many important implications or to have tested adequately their empirical assumptions. It is not clear that the "problem" is a "problem," notwithstanding the appeal of the proposed solution, and it not clear that the proposed solution is wise even if the problem really exists. Other approaches, such as enhanced supervisory techniques, may present better alternatives.

It is not the imposition of new applications of technology itself that is controversial, but instead the allocations of risks and burdens that would arise from or be displaced by changes in the systems. At least in the short run, the market will not necessarily reach the most efficient result when entrenched players are creating a single system to be employed by all intermediaries, with the costs to be passed on to investors. The enchanting elegance of a new system that seeks to solve a perceived problem can be misleading. At bottom, the promise of automation cannot shelter decisionmakers from the persistent empirical, behavioral, economic, and normative issues that must be faced in resolving any issue of public policy.

In the longer run, the prospects seem good for continued reductions in risk through the implementation of proposals such as DCRS. Competition for investors and transactions between and among markets (New York, London, and Tokyo, for example) should provide increasing incentives to move toward 
safer and more efficient front- and back-office systems. Satisfaction with adequate, if not optimal, systems ("if it ain't broke, don't fix it") could result in one market or another being left behind. Further, the Unpredictability feature of information technology suggests that investments will be made on the chance that improvements will result, even when the characteristics and extent of the benefits remain uncertain.

\section{Choices Influenced by Technology: Federal/State Laws, Statutes/Administrative Regulations, Statutory Drafting, and International Harmonization}

The attributes of information technology can influence choices about the appropriate source and character of commercial law. For example, the Frequent Change, System Complexity, and Technology Complexity attributes suggest that administrative regulations, which can be amended with relative ease, may be superior to statutes alone in dealing with information technology driven markets. ${ }^{88}$ Similarly, when compared to state legislation, federal law and regulations can offer enhanced uniformity and flexibility. ${ }^{89}$ Information technology has been successfully employed in the process of designing statutory language structures. ${ }^{90}$ Finally, the important role of information technology in the evolution of truly global markets has made the need for harmonization among various legal and regulatory regimes increasingly important. ${ }^{91}$

88. As David Goldstein has observed,

in a high technology area, existing conditions can be expected to change. Adoption and widespread implementation of amendments to the Uniform Commercial Code to address interpretational problems and changes in the industry could be glacially slow.... [T] his is a process that takes years, rather than months, in an industry [banking] that may not be able to live for years with a legislated problem.

This argues for governmental supervision through regulation. A regulatory scheme would allow changes to be made far more easily and rapidly as conditions change and inadequacies in the initial regulation are identified.

David B. Goldstein, Federal Versus State Adoption of Article 4A, 45 Bus L 1513, 1517-18 (1990) (footnote omitted); see also Edward L. Rubin, Uniformity, Regulation, and the Federalization of State Law: Some Lessons from the Payment System, 49 Ohio St L J 1251, 1272 (1989) (an administrative regulatory regime is superior to a legislative one in keeping operational rules up-to-date and in making and responding to innovation).

89. Again according to Goldstein, "a scheme under state-by-state enactment could result in nonuniform regulations from state to state, and thereby defeat the purpose of having a uniform statute. On the other hand, regulation under a federal statute would clearly be practical." Goldstein, 45 Bus $\mathrm{L}$ at 1518 (cited in note 88) (footnotes omitted); see also Rubin, 49 Ohio St $\mathrm{L} \mathrm{J}$ at 1265-68 (cited in note 88 ). The "federalization" of commercial law is a widely debated, controversial, and complex subject. See, for example, Robert Braucher, Federal Enactment of the Uniform Commercial Code, 16 L \& Contemp Probs 100 (1951); Barkley Clark, Secured Transactions, 42 Bus L 1333 (1987); Charles W. Mooney, Jr., Introduction to the Uniform Commercial Code Annual Survey: Some Observations on the Past, Present, and Future of the UCC, 41 Bus L 1343 (1986); David M. Phillips, Secured Credit and Bankruptcy: A Call for the Federalization of Personal Property Security Law, 50 L \& Contemp Probs 53 (1987); E. Hunter Taylor, Jr., Foreword: Federalism or Uniformity of Commercial Law, 11 Rutgers Camden L J 527 (1980).

90. See, for example, Grayfred B. Gray, Reducing Unintended Ambiguity in Statutes: An Introduction to Normalization of Statutory Drafting, 54 Tenn L Rev 433 (1987).

91. See OTA, Trading Around the Clock at 3 (cited in note 1) ("One of the shared conclusions of these studies [of international clearing and settlement] is that the world's major clearing and settlement systems should be 'harmonized' in selected ways in order to strengthen them and prepare 


\section{ConClusion}

This article began by identifying several general attributes of information technology. It hypothesized that this taxonomy could enlighten and benefit those who create, administer, and interpret law. It next considered, in the penumbra of these attributes, various specifics of securities transfer and securities market clearance and settlement. Along the way, some general observations were made about the interaction between the characteristics of information technology and the creation, administration, and interpretation of law. Other observations remain to be made explicit here.

The seemingly clear and consistent trends relating to information technology are tempered by the technology's inherently countervailing unpredictability. Opting for laws that are flexible and general instead of rigid and specific may prove to be an important strategy for lawmakers. On the other hand, there may be times when it is best to implement a specific "best guess" at what kind of legal regime may be needed in the future. The revised article 8's regime for uncertificated securities is a case in point. On a more general level, we might aspire to laws that are paper-neutral and that take into account all forms of communication-even forms that cannot be imagined. The challenge is obvious. Perhaps "technology impact statements" should accompany new laws and regulations, thereby encouraging lawmakers to consider the effect of law on, and the effects on law of, information technology.

Purging detail from laws that regulate such matters as property claims and financial transactions does not alone provide an adequate response to the information age. There will remain contexts where explicit detail and guidance is desirable. The gap might be bridged by administrative regulations that can be modified more easily and rapidly. Regulations on the federal level could address matters traditionally governed by state statutory law.

Information technology has been proven useful in the context of statutory drafting. But the attributes of information technology call into question more than the source, style, and structure of law. For example, information technology provides an opportunity to rethink the substantive underpinnings of the regulatory and supervisory approaches toward financial institutions that were developed in the first half of this century. And as the social benefits of information technology applications increase, they may incrementally outweigh some of the perceived costs, such as the diminution of privacy.

\footnotetext{
for the emerging global (rading environment."). Suppose an investor wishes to buy securities on Wednesday morning in New York (Wednesday night in Tokyo) and re-sell the same securities on Thursday morning in Tokyo (Wednesday night in New York). If Tokyo settlement were to occur on $T+3$ and if New York settlement were to occur on $T+5$, the investor could not meet its settlement obligation in Tokyo on $T+3$ (unless it incurred the cost of borrowing securities) because it would not yet have received the securities in New York. This simple example illustrates the importance of harmonization to efforts to link the world's markets.
} 
Some of the attributes of information technology are not unique to it. For example, the foregoing discussion of costs and benefits of a DRCS-type system illustrated that the questions of whether and how to apply information technology in a given context pose the same kinds of difficulties that are involved in resolving any issue of law reform or social policy. Similarly, the Frequent Change and Unpredictability attributes also are apt descriptions of the financial markets generally in recent years, where most of the significant events were thought to have been impossible shortly before they occurred. The following come to mind: a prime rate of 21 percent; the de facto failure of Continental Bank brought on by purchasing participations in loans generated by an Oklahoma City shopping center bank; a more than 500-point fall in the Dow Jones Industrial Average in one day; a $\$ 24$ billion leveraged buyout (RJR Nabisco); allowing hundreds of insolvent $S$ \& Ls to continue operations; Texaco's Chapter 11 filing brought on by a single tort judgment; and the Failure of Drexel, Burnham, Lambert, the high-flying securities firm darling of the 1980s. As the realization emerges that the "impossible" is the "normal" in the financial markets, perhaps the same realization will increasingly be seen as applicable to information technology.

Notwithstanding the arrival of the information age, based on my anecdotal observations and involvement in various "law reform" projects, my impression is that for players in the legal theater, it is largely "business as usual." Not surprisingly, close attention is paid to information technology in the study of legal regulation of technology dominated relationships and transactions, such as electronic data interchange, computerized public filing systems, property attributes of information, electronic funds transfer, and electronic letters of credit-topics treated or mentioned elsewhere in this symposium issue. But I submit that more thought, dialogue, and energy should be directed toward formulating a more generalized and principled approach to taking account of information technology in the legal process. And if it is to be influential and successful, a more generalized approach must be useful, visible, and understandable to actors in the legal system who are not "techies." 92 Perhaps the generalizations articulated in this article will assist and inform that project.

92. The suffix -nik "convert[s] a verb, noun or adjective into a colorful pejorative for an ardent lover, cultist or devotee of something ...." Leo Rosten, Hooray for Yiddish 233 (Touchstone ed, 1984). -Nik implies an uncritical or poorly informed enthusiast, as contrasted to a maven, or expert. Id at 207. Krier \& Gillette, 84 Mich L Rev at $407 \mathrm{n} 7$ (cited in note 74). I use the term "techie" to include both techniks and technology mavens. 